\title{
Influence of Varying Environment on Rice Varieties under Upland Condition of Madhya Pradesh, India
}

\author{
Girdhari Nargave*, P. B. Sharma, Rajendra Prashad Sahu, \\ Vikash Singh and Rajendra Patel
}

Department of Agronomy, College of Agriculture, Jabalpur

Jawaharlal Nehru Krishi Vishwa Vidyalaya, Jabalpur (M.P.) 482004, India

*Corresponding author

\section{A B S T R A C T}

The field experiment was conducted during Kharif season of 2018 at Research farm, Department of Physics and Argo-meteorology, College of Agricultural Engineering, JNKVV, Jabalpur (M.P.). Aim of the study is to evaluate the

Keywords

Dates of sowing, Varieties, Direct seeded rice, Yield and Economics

\section{Article Info}

Accepted:

15 July 2020

Available Online:

10 August 2020 performance of rice cultivar under varying environment. Keeping 3 dates of sowing i.e., $15^{\text {th }}$ June, $30^{\text {th }}$ June and $15^{\text {th }}$ July under main plots and four rice varieties viz., MTU 1010, Sahbhagi, Kranti and IR 36 in sub plot with thrice replications. The experiment was laid out in split plot design. The direct seeded rice sown on $15^{\text {th }}$ June was found most favourable for all 4 rice cultivar and maximum mean yield was option under this date of sowing. Among the rice cultivar the Kranti performed significance superior over rest of varies at all dates of sowing. Results revealed that direct seeded rice sown on $15^{\text {th }}$ June recorded significantly higher grain yield $\left(3742 \mathrm{~kg} \mathrm{ha}^{-1}\right)$ as compared to $30^{\text {th }} \mathrm{June}(3482 \mathrm{~kg}$ $\left.\mathrm{ha}^{-1}\right)$ and $15^{\text {th }}$ July $\left(3065 \mathrm{~kg} \mathrm{ha}^{-1}\right)$. Rice variety Kranti showed significant superiority over other varieties under all the three dates i.e., $15^{\text {th }} \mathrm{June}, 30^{\text {th }}$ June and $15^{\text {th }}$ July sowing in terms of grain yield. The net monetary returns and B: C ratio were found to be the maximum (Rs.39736 ha ${ }^{-1}$ and 2.0, respectively) under Kranti variety sown on $15^{\text {th }}$ June.

\section{Introduction}

Rice (Oryza sativa L.) plant belonging to the family of Poaceae (Gramineae). It is the most important staple food in Asia, providing average $32 \%$ of total calorie uptake (Singh et al., 2019a and Singh et al.,
2019b).Worldwide, rice is grown on $167 \mathrm{mha}$, with an annual production of about 769.65 million tonnes of paddy (FAO, 2017). India accounts for $22.3 \%$ of the world's production of rice. India is the $2^{\text {nd }}$ largest producer and consumer of rice in the world. At present, 43.19 million hectare area is under rice crop 
in India with the production of 109.70 million tonnes and the productivity of $2550 \mathrm{~kg}$ ha ${ }^{1}$ (Anonymous, 2017). In Madhya Pradesh, rice is grown in about 2.02 million hectare area with the production of 3.58 million tonnes which clearly indicates that the productivity of rice is quite low i.e., $1768 \mathrm{~kg}$ $\mathrm{ha}^{-1}$ (Anonymous, 2016). Based on the hydrology and topography of land, the rice area is classified into various ecologies viz., rainfed upland (16\%), irrigated medium land (45\%) and rainfed low land (39\%).Rice crop needs a hot and humid climate. It is best suited to regions which have high humidity, prolonged sunshine and an assured supply of water.Direct seeding technique offers a useful option to reduce the limitations of transplanted rice (Pingali et al., 1994). Direct seeding can also reduce the risk by avoiding terminal drought that lowers the yield of transplanted rice, especially if the latter is established late due to delayed rainfall. Direct seeding can facilitate crop intensification (Singh et al., 2008).

Under upland condition, an early maturing variety of 100-110 days duration e.g. Sahbhagi, MTU 1010, Annapurna, Jagruthi are grown, while under irrigated lowland condition medium to long duration varieties like Kranti, IR-36, Madhuri are generally preferred. In direct seeded rice the medium or late maturing varieties suffer due to water stress at maturity stage. The reasons of low productivity of rice in rainfed lowland ecosystem are many and varied. Therefore, keeping in view all above facts the present investigation entitled influence of varying environment on rice varieties under upland condition.

\section{Materials and Methods}

The field experiment was conducted at Research Farm, Department of Physics and Agro-meteorology, College of Agricultural
Engineering, JNKVV, Jabalpur (M.P.) during Kharif season of 2018. The climate is subhumid, sub-tropical and featured by hot dry summer and cool dry winter. The soil of experimental field was sandy clay loam in texture and neutral in reaction $(\mathrm{pH} \mathrm{6.72)} \mathrm{with}$ low electrical conductivity $(0.06 \mathrm{dS} / \mathrm{m})$ and medium in available $\mathrm{N}\left(285 \mathrm{~kg} \mathrm{ha}^{-1}\right), \mathrm{P}(17.45$ $\left.\mathrm{kg} \mathrm{ha}^{-1}\right), \mathrm{K}$ (260 kg ha-1) and organic carbon $(0.82 \%)$. The field experiment was laid out in split plot design with replicated thrice. The treatments comprised of three dates of sowing $\left(15^{\text {th }}\right.$ June, $30^{\text {th }}$ June and $15^{\text {th }}$ July) in main plots and four varieties (MTU 1010, Sahbhagi, Kranti and IR 36) in sub plots. Seed of rice were sown on June $15^{\text {th }}$, June $30^{\text {th }}$ and July $15^{\text {th }}$ by direct seeded in lines $20 \mathrm{~cm}$ apart keeping a seed rate of $60 \mathrm{~kg} \mathrm{ha}^{-1}$. All recommended package and practice for nutrient, water and weed management were adopted to grow the rice crop. The seeds were treated with Bavistin @ $2 \mathrm{gkg}^{-1}$ seed before sowing.

\section{Results and Discussion}

\section{Effect of dates of sowing}

Data given in Table 1 indicated that, the dates of sowing significantly influenced the yield attributes of rice. Sowing on $15^{\text {th }}$ June gave significant highest number of effective tillers $\left(361 \mathrm{~m}^{-2}\right)$, length of panicle $(24.58 \mathrm{~cm})$, number of filled grains panicle ${ }^{-1}$ (128), weight per panicle $(3.06 \mathrm{~g})$ and 1000 grain weight $(22.81 \mathrm{~g})$ as compared to $30^{\text {th }}$ June effective tillers $\left(354 \mathrm{~m}^{-2}\right)$, length of panicle $(23.63 \mathrm{~cm})$, number of filled grains panicle ${ }^{-1}(125)$, weight panicle $^{-1}(2.90 \mathrm{~g})$ and 1000 grain weight (22.44) and $15^{\text {th }}$ July effective tillers $\left(334 \mathrm{~m}^{-2}\right)$, length of panicle $(21.65 \mathrm{~cm})$, number of filled grains panicle $^{-1}(119)$, weight panicle ${ }^{-1}(2.85 \mathrm{~g})$ and 1000 grain weight (20.72). This may be due to availability of favourable soil and air temperature during growing cycle of the crop. Under late sowing condition the shortened the 
growth period of the plant which reduced the leaf area, length of panicle and number of filled grainspanicle ${ }^{-1}$ than early sowing. Number of filled grains penicle ${ }^{-1}$ was found in the decreasing trend from the seeding of $15^{\text {th }}$ June onward. Grains panicle ${ }^{-1}$ showed better response with early sowing (Biswas and Salokhe, 2001). Besides, a reduction in the grain filling rate was also noted under low temperature. This show that the environmental condition likes temperature, humidity is most favourable for grain development in early transplanting as compared to delay transplanting (Akbar et al., 2010).Early seeding (15 June) had the highest 1000-grain weight and decreased as sowing delayed. 1000-grain weight decreased gradually with delay in planting time.

The dates of sowing significantly influenced the grain yield of rice. Sowing on $15^{\text {th }}$ June recorded maximum grain and straw yield (3742 and $6737 \mathrm{~kg} \mathrm{ha}^{-1}$, respectively) which was significantly higher than the grain and straw yield under as $30^{\text {th }}$ June (3482 and 6556 $\mathrm{kg} \mathrm{ha}^{-1}$, respectively) and $15^{\text {th }}$ July (3065 and $6203 \mathrm{~kg} \mathrm{ha}^{-1}$, respectively).

The higher paddy yield was attributed to more number of effective tillers, more number of filled grains panicle ${ }^{-1}$ and increased 1000 grains weight. Delay in sowing results in reduction of plant height, productive tillers, filled grain panicle ${ }^{-1}$ and grain yield as also was reported by Shah and Bhurer (2005). The higher yield for early sowing was mainly due to favourable climatic conditions especially at the time of tillering, flowering and grain filling (Jagtap et al., 2017). Table 1 indicated that with each delay in sowing of rice, there was significant decrease in grain yield of rice during the crop seasons. Similar results were reported by Dhaliwal (2006) and Mahajan (2009). Rice grain yields declined as seeding date was delayed (Hwang et al., 1998).

\section{Effect of varieties}

Data presented in Table 1 revealed that, at harvest stage, among the varieties Kranti produced significantly highest effective tillers $\left(370 \mathrm{~m}^{-2}\right)$ as compared to Sahbhagi $\left(354 \mathrm{~m}^{-2}\right)$ and IR $36\left(341 \mathrm{~m}^{-2}\right)$, while MTU 1010 variety gave lowest effective tillers $\left(330 \mathrm{~m}^{-2}\right)$. Among the varieties Kranti produced significantly higher length of panicle $(24.71 \mathrm{~cm})$ as compared to Sahbhagi $(23.53 \mathrm{~cm})$ and IR 36 $(22.71 \mathrm{~cm})$, while MTU 1010 exhibited minimum length of panicle $(22.19 \mathrm{~cm})$, which was at par to that of IR 36. Among the varieties Kranti recorded significantly higher number of filled grains panicle ${ }^{-1}$ (130) followed by Sahbhagi (123), IR 36 (123) and MTU 1010 (118). Variation in filled grains panicle $^{-1}$ was observed due to genotypic differences of varieties. Similar results were reported by earlier worker Kumhar et al., 2016a and Kumhar et al., 2016b. Among the varieties Kranti exhibited significantly weight panicle $^{-1}(3.36 \mathrm{~g})$ as compared to Sahbhagi (2.97g) and IR 36 (2.76g), while MTU 1010 variety exhibited lowest weight of per panicle (2.65 g).

The 1000 grain weight (g) of different varieties varied significantly. Variety Kranti (23.98) recorded significantly maximum test weight over others. Among the varieties Kranti produced significantly higher grain and straw yield $\left(3938\right.$ and $6901 \mathrm{~kg} \mathrm{ha}{ }^{-1}$, respectively) as compared to Sahbhagi (3407 and $6448 \mathrm{~kg} \mathrm{ha}^{-1}$, respectively) IR 36 (3241 and $6319 \mathrm{~kg} \mathrm{ha}^{-1}$, respectively) and MTU 1010 (3134 and $6328 \mathrm{~kg} \mathrm{ha}^{-1}$, respectively). Applying additional irrigation at flowering stage besides managing under rainfed situation improved grain yield of Kranti variety as was also reported by Bedi (2012).The results are in the conformity with the work done by Padhi (1995) and Mahajan (2009). 


\section{Interaction effects}

Data presented in Table 2 revealed that, the interaction effects between dates of sowing and different varieties were found to be significant in respect of grain and straw yield $\left(\mathrm{kgha}^{-1}\right)$ of rice. Variety Kranti under $15^{\text {th }}$
June sowing gave highest grain and straw yield (4263 and $6964 \mathrm{~kg} \mathrm{ha}^{-1}$, respectively) which was significantly superior over other treatment combinations. However, variety MTU 1010 under $15^{\text {th }}$ July sowing gave minimum grain yield of $2734 \mathrm{~kg} \mathrm{ha}^{-1}$.

Table.1 Effective tillers, panicle length, filled grain panicles ${ }^{-1}$, grain weight panicle ${ }^{-1}$, test weight (1000 grain weight), grain and straw yield of rice as influenced by different dates of sowing and varieties

\begin{tabular}{|c|c|c|c|c|c|c|c|}
\hline Treatments & $\begin{array}{l}\text { Effective } \\
\text { tillers } \mathbf{m}^{-}\end{array}$ & $\begin{array}{l}\text { Panicle } \\
\text { length } \\
\text { (cm) }\end{array}$ & $\begin{array}{c}\text { Filled } \\
\text { grains } \\
\text { panicle }^{-1}\end{array}$ & $\begin{array}{c}\text { Grain } \\
\text { weight } \\
\text { panicle }^{-1}(g)\end{array}$ & $\begin{array}{c}\text { Test } \\
\text { weight } \\
\text { (g) }\end{array}$ & $\begin{array}{c}\text { Grain } \\
\text { yield (Kg } \\
\left.\text { ha }^{-1}\right)\end{array}$ & $\begin{array}{c}\text { Straw } \\
\text { yield } \\
\left(\text { Kg ha }^{-1}\right)\end{array}$ \\
\hline \multicolumn{8}{|l|}{ Dates of sowing } \\
\hline D1-15 ${ }^{\text {th }}$ June & 361 & 24.58 & 128 & 3.06 & 22.81 & 3742 & 6737 \\
\hline D2-30 ${ }^{\text {th }}$ June & 354 & 23.63 & 125 & 2.90 & 22.44 & 3482 & 6556 \\
\hline D3-15 ${ }^{\text {th }}$ July & 334 & 21.65 & 119 & 2.85 & 20.72 & 3065 & 6203 \\
\hline SEm \pm & 1.0 & 0.9 & 0.29 & 0.01 & 0.11 & 43.65 & 89.07 \\
\hline CD at $5 \%$ & 4.2 & 0.36 & 1.17 & 0.04 & 0.46 & 175.92 & 359.11 \\
\hline \multicolumn{8}{|l|}{ Varieties } \\
\hline V1-MTU 1010 & 330 & 22.19 & 118 & 2.65 & 21.03 & 3134 & 6328 \\
\hline V2-Sahbhagi & 354 & 23.53 & 123 & 2.97 & 22.00 & 3407 & 6448 \\
\hline V3-Kranti & 370 & 24.71 & 130 & 3.36 & 23.98 & 3938 & 6901 \\
\hline V4-IR 36 & 341 & 22.71 & 123 & 2.76 & 21.66 & 3241 & 6319 \\
\hline SEm \pm & 2.0 & 0.19 & $\mathbf{0 . 3 0}$ & 0.01 & 0.11 & 23.15 & 50.89 \\
\hline CD at $5 \%$ & 6.0 & 0.57 & 0.91 & 0.04 & 0.46 & 69.32 & 152.38 \\
\hline
\end{tabular}

Table. 2 Interaction effect of the sowing times and varieties on grain yield $\left(\mathrm{kg} \mathrm{ha}^{-1}\right)$ and Straw yield $\left(\mathrm{kg} \mathrm{ha}^{-1}\right)$ of direct seeded rice (DSR)

\begin{tabular}{|c|c|c|c|c|c|c|c|c|}
\hline \multirow[b]{2}{*}{ Treatments } & \multicolumn{4}{|c|}{ Grain yield $\left(\mathrm{kg} \mathrm{ha}^{-1}\right)$} & \multicolumn{4}{|c|}{ Straw yield $\left(\mathrm{kg} \mathrm{ha}^{-1}\right)$} \\
\hline & $\begin{array}{l}15^{\text {th }} \\
\text { June }\end{array}$ & $\begin{array}{c}30^{\text {th }} \\
\text { June }\end{array}$ & $15^{\text {th }}$ July & Mean & $\begin{array}{l}15^{\text {th }} \\
\text { June }^{2}\end{array}$ & $\begin{array}{l}\mathbf{3 0}^{\mathbf{t h}} \\
\text { June }\end{array}$ & $\begin{array}{l}15^{\text {th }} \\
\text { July }\end{array}$ & Mean \\
\hline MTU 1010 & 3426 & 3240 & 2734 & 3134 & 6727 & 6390 & 5868 & 6328 \\
\hline Sahbhagi & 3735 & 3435 & 3049 & 3407 & 6642 & 6413 & 6289 & 6448 \\
\hline Kranti & 4263 & 3948 & 3602 & 3938 & 6964 & 6919 & 6820 & 6901 \\
\hline IR-36 & 3542 & 3307 & 2875 & 3241 & 6615 & 6504 & 5838 & 6319 \\
\hline Mean & 3742 & 3482 & 3065 & & 6737 & 6556 & 6203 & \\
\hline & $\mathrm{D}$ & $\mathrm{V}$ & $\mathrm{D} \times \mathrm{V}$ & $\mathrm{V} \times \mathrm{D}$ & $\mathrm{D}$ & $\mathrm{V}$ & $\mathrm{D} \times \mathrm{V}$ & $\mathrm{V} \times \mathrm{D}$ \\
\hline SEm \pm & 43.6 & 23.1 & 55.7 & 87.2 & 89.0 & 50.8 & 117.3 & 178.1 \\
\hline $\mathrm{CD}(\mathbf{P}=\mathbf{0 . 0 5})$ & 175.9 & 69.3 & 202.4 & 145.5 & 359.1 & 152.3 & 421.4 & 316.6 \\
\hline
\end{tabular}


Table.3 Cost of cultivation, gross monetary returns, net monetary returns and B: C ratio of different dates of sowing and varieties under direct seeded rice

\begin{tabular}{|c|c|c|c|c|}
\hline Treatments & $\begin{array}{c}\text { Cost of } \\
\text { cultivation } \\
\left(\text { Rs. ha } \text { ha }^{-1)}\right.\end{array}$ & $\begin{array}{l}\text { Gross monetary } \\
\text { returns (Rs. ha }{ }^{-1)}\end{array}$ & $\begin{array}{c}\text { Net monetary } \\
\text { returns } \\
\left(\text { Rs. ha }{ }^{-1)}\right.\end{array}$ & B: C ratio \\
\hline \multicolumn{5}{|l|}{ Dates of sowing } \\
\hline D1-15 ${ }^{\text {th }}$ June & 39236 & 78960 & 39736 & 2.0 \\
\hline D2-30 ${ }^{\text {th }}$ June & 38536 & 74063 & 35527 & 1.9 \\
\hline D3-15 ${ }^{\text {th }}$ July & 37836 & 66042 & 28206 & 1.7 \\
\hline \multicolumn{5}{|l|}{ Varieties } \\
\hline V1-MTU 1010 & 37836 & 67494 & 29658 & 1.8 \\
\hline V2-Sahbhagi & 37836 & 72512 & 34676 & 1.9 \\
\hline V3-Kranti & 39236 & 82717 & 43481 & 2.1 \\
\hline V4-IR 36 & 39236 & 69364 & 30128 & 1.8 \\
\hline
\end{tabular}

The higher grain yield in $15^{\text {th }}$ June sown crop may be attributed to better plant growth leading to significantly more number of tillers $\mathrm{m}^{-2}$, number of grains panicle $\mathrm{e}^{-1}$, number of effective tillers $\mathrm{m}^{-2}$, number of filled grains panicle $^{-1}$ and 1000-seed weight (g) just because of better partitioning of photosythates compared to delayed sowing dates. Delay in sowing results in reduction of plant height, effective tillers, filled grain panicle $^{-1}$ and grain yield as also was reported by Shah and Bhurer (2005). Sartori et al., (2013) also obtained highest yield from early sown rice crop whereas poorer grain and straw yield were obtained from late sown rice. Short photoperiod induces high partitioning of assimilates to rice grains as was also reported by Pallavi et al., (2018).

\section{Economics of the treatments}

The economic indices calculated for various treatments have been given in Table 3 . Sowing of upland rice on $15^{\text {th }}$ June proved most beneficial giving maximum net monetary returns of Rs. 39736 ha $^{-1}$ with B: C ratio of 2.0. Fifteen days delay in sowing i.e., $30^{\text {th }}$ June resulted in reduced net monetary returns of Rs. 35527 ha $^{-1}$ with B: C ratio of 1.9. Under $15^{\text {th }}$ July, the net monetary returns was further reduced to Rs. $28206 \mathrm{ha}^{-1}$ with B: $\mathrm{C}$ ratio of 1.7. Late sowing adversely influenced the yield and there by net monetary returns. These results are in accordance to the findings of Singh et al., (1997) who reported that net monetary returns and benefit cost ratio were also higher in case of 15 June sowing. In case of rice varieties, Kranti proved its superiority by giving highest net monetary returns up to Rs. $43481 \mathrm{ha}^{-1}$ with $\mathrm{B}$ : $\mathrm{C}$ ratio of 2.1. However, the second best variety was Sahbhagi giving net income up to Rs. 34676 ha $^{-1}$ with B: C ratio of 1.9. The third best variety was IR 36 nearby giving net monetary returns up to Rs. 30128 ha $^{-1}$ with B: C ratio of 1.8 and MTU 1010 giving lowest net monetary returns up to Rs. $29658 \mathrm{ha}^{-1}$ with B: C ratio of 1.8. Accordingly the $15^{\text {th }}$ June sowing of Kranti variety proved to be the most remunerative with the net monetary returns of Rs. $48593 \mathrm{ha}^{-1}$ and B: C ratio of 2.2. A difference in net monetary returns from different varieties has also been reported by Singh (2006) and Jain and Upadhaya (2008).

From the experiment, it is concluded that the optimum sowing date for direct seeding of upland rice variety Kranti is $15^{\text {th }}$ June for getting maximum yield and net monetary 
returns, while delay in sowing after $30^{\text {th }}$ June and $15^{\text {th }}$ July reduce the yield gradually. Growth, yield attributes and grain yield of direct seeded rice were affected by dates of sowing. The maximum grain yield of $3742 \mathrm{~kg}$ $\mathrm{ha}^{-1}$ was found under $15^{\text {th }}$ June sowing, which was significantly higher over the yield under $30^{\text {th }}$ June (3482 $\left.\mathrm{kg} \mathrm{ha}^{-1}\right)$ and $15^{\text {th }}$ July (3065 $\left.\mathrm{kg} \mathrm{ha}^{-1}\right)$. All the varieties showed higher yield in $15^{\text {th }}$ June sowing while reduction in growth, yield attributes and grain yield with successive 15 days delay in sowing. Rice variety Kranti showed more remunerative other varieties under all the three dates i.e., $15^{\text {th }}$ June, $30^{\text {th }}$ June and $15^{\text {th }}$ July sowing in terms of grain yield.

\section{References}

Akbar N, Iqbal A, Khan HN, Hanif, MK and Basir MV. 2010. Effect of different sowing dates on the yield and yield component of direct seeded rice ( L.) Journal of Plant Breeding and Crop Science, 2(10): 312-315.

Anonymous. 2016. Directorate of Economics and Statistics, Department of Agriculture and Co-operation, Govt. of India, New Delhi.

Anonymous. 2017. Directorate of Economics and Statistics. Ministry of Agriculture, Government of India, New Delhi.

Bedi N. 2012. Evaluation of Rice Varieties under Different Agro-Ecosystems and Weed Competitiveness in Vertisol in Kymore plateau and Satpura Hills Zone of M.P. M.Sc. Thesis, JNKVV, Jabalpur. 54p.

Biswas PK and Salokhe VM. 2001. Effects of planting date, intensity of tiller separation and plant density on the yield of transplanted rice. Journal of Agricultural Science. 137(3): 279-287.

Dhaliwal LK, Hundal SS, Chahal SK and Aneja A. 2006. Effect of conventional and furrow planting methods on radiation interceptopn, growth and yield of rice paddy. Proceedings of the international workshop on Water saving practices in rice paddy cultivation 14-15 September, Kaulalumpur (Malalysia).

FAO. 2017. Statistical Databases. Food and Agriculture Organization (FAO) of the United Nations, Rome. http://www.Fao.org.

Hwang CD, Shin DK, Lee KY, Park ST, Park ST and Kim SC. 1998. The critical seeding date of corrugated furrow rice in eastern coastal area. J. Crop Sci. 40:62-69.

Jagtap DN, Mahadkar UV and Chavan SA. 2017. Response of rice varieties to different sowing windows under Konkan conditions. Agricultural Science Digest 37(1): 78-80.

Jain A and Upadhaya VB. 2008. Effect of planting geometery and seedling on the performance of inbred and hybrid rice under SRI. Haryana Journal of Agriculture 24(1\&2):16-18.

Kumhar BL, Chavan VG, Rajemahadik VA, Kanade VM, Dhopavkar RV, Ameta HK and Tilekar RN. 2016a. Effect of different rice establishment methods on growth, yield and different varieties during kharif season. Int. J. Plant, Ani. Env. Sci., 6 (2), 127-131.

Kumhar BL, Ameta HK and Rewar SK. 2016b. Direct seeded rice is a reduce input of rice production in India- A Review. Journal Progressive Agri. 7 (1)17-19.

Mahajan G, Bharaj TS and Timsina J. 2009. Yield and water productivity of rice as affected by time of transplanting in Punjab, India. Agricultural Water Management, 96: 25-32.

Padhi AK. 1995. Response of rainfed rice to sowing times. Pp. 124-126.

Pallavi S, Sharma RS and Shukla A. 2018. Evaluation of growing degree days (gdd) values of early, normal and late 
sowing dates in different genotypes of rice (Oryza sativa L.). International Journal of Agriculture Sciences 10 (7): pp.-5655-5659.

Pingali PL and Rosegrant MW. 1994. Confronting the environmental consequences of the green revolution. In: Proceedings of the 18th Session of the international Rice Commission, Rome. FAO, Rome, Italy, pp. 59-69.

Sartori GMS, Marchesan E, Azevedo CF, Streck NA, Roso R, Coelho LL and Oliveira ML. 2013. Grain yield and water use efficiency in irrigated rice according to sowing date. Ciencia Rural 43(3): 397-403.

Shah LM and Bhurer KP 2005. Response of wet seeded rice varieties to sowing dates. Nepal Agricultural Research Journal 6: 35-38.

Singh KM, Pal SK, Verma UN, Thakur R and Singh MK. 1997. Effect of time and methods of planting on performance of rice (Oryza sativa) cultivars under medium land of Bihar plateau. Indian J. Agron. 42(3):443-445.
Singh SP. Sreedevi B. Kumar RM and Subbaiah SV. 2008. Grain yield and economics of wet direct sown rice under different establishment methods and nitrogen schedules. Oryza 45(3):245246.

Singh V, Agrawal KK, Jha AK and Sahu MP. 2019a. Effect of Forchlorfenuron on Yield and Economics of Transplanted Rice, Ind. J. Pure App. Biosci. 7(4), 411-414.

Singh V, Agrawal KK and Jha AK. 2019b. Effect of Forchlorfenuron on growth and yield of rice (Oryza sativa L.) during Kharif season of Central India. Int.J.Curr.Microbiol.App.Sci. 8(09): 2331- 2338.

Singh YP, Singh G, Singh SP, Kumar A, Sharma G, Singh MK, Mortin M and Johnson DE. 2006. Effect of weed management and crop establishment methods on weed dynamics and grain yield of rice. Indian J. Weed Sci., 38 (1 and 2): 20-24.

\section{How to cite this article:}

Girdhari Nargave, P. B. Sharma, Rajendra Prashad Sahu, Vikash Singh and Rajendra Patel. 2020. Influence of Varying Environment on Rice Varieties under Upland Condition of Madhya Pradesh, India. Int.J.Curr.Microbiol.App.Sci. 9(08): 1317-1323.

doi: https://doi.org/10.20546/ijcmas.2020.908.149 